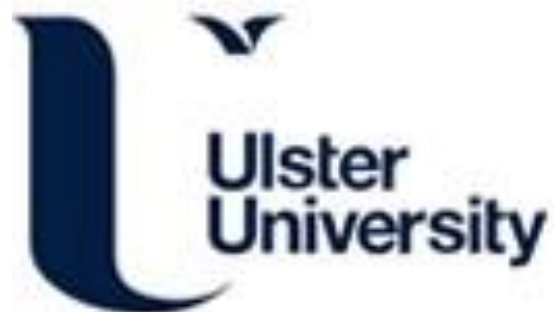

\section{Sandy barrier overstepping and preservation linked to rapid sea level rise and geological setting}

Cooper, A., Green, A., Meireles, R., Klein, A., Souza, J., \& Toldo, E. (2016). Sandy barrier overstepping and preservation linked to rapid sea level rise and geological setting. Marine Geology, 382, 80-91.

https://doi.org/10.1016/j.margeo.2016.10.003

Link to publication record in Ulster University Research Portal

\section{Published in:}

Marine Geology

Publication Status:

Published (in print/issue): 01/12/2016

DOI:

10.1016/j.margeo.2016.10.003

\section{Document Version}

Author Accepted version

\section{General rights}

Copyright for the publications made accessible via Ulster University's Research Portal is retained by the author(s) and / or other copyright owners and it is a condition of accessing these publications that users recognise and abide by the legal requirements associated with these rights.

\section{Take down policy}

The Research Portal is Ulster University's institutional repository that provides access to Ulster's research outputs. Every effort has been made to ensure that content in the Research Portal does not infringe any person's rights, or applicable UK laws. If you discover content in the Research Portal that you believe breaches copyright or violates any law, please contact pure-support@ulster.ac.uk. 
Sandy barrier overstepping and preservation linked to rapid sea level rise and geological setting J.A.G. Cooper, A.N. Green, R.P. Meireles, A.H.F. Klein, J. Souza, E.E. Toldo

\begin{abstract}
In an era of global rising sea level quantifying future shoreline behaviour is a key societal concern. The potential for dramatic shoreline change via overstepping or barrier disintegration on barrierlagoon coasts as a result of future rapid sea level rise has been considered by various authors, but documented examples of barrier overstepping generally involve either coarse grain sizes or early diagenesis as beachrock. Where overstepping has been inferred, the overstepped barrier is seldom preserved. Using high resolution seismic data we describe the mid-Holocene overstepping of a sandy coastal barrier system and subsequent geomorphological changes that ultimately transformed it into a strandplain fronted by amuddy shoreface. This complete change in character is interpreted in the context of rapid sea level rise (tentatively linked to the 8.2 ka event) during which the former sandy shoreface-barrier was overstepped and decoupled from the contemporary shoreline, leaving the latter sand-starved. Upon overstepping, the wave-influenced shoreline was displaced rapidly to the landward margin of the former lagoon. Preservation of the overstepped uncohesive sandy barrier is attributed to the relatively wave-sheltered location, rapid sea level rise and rapid burial by shoreface sediments. This situation provides an insight into the conditions under which overstepping occurs, and thereby, the future response of barrier lagoon systems to predicted rapid rates of future sea level rise.
\end{abstract}

\title{
Introduction
}

The response of coastal barrier and backbarrier systems to future sea level rise is an issue of widespread concern because of the global extent of barrier shorelines (Stutz and Pilkey, 2011) and the widespread development on and around them (Nordstrom, 2004).Historical scale studies of evolving barrier morphology point to several behavioural responses to sea level rise, all of which are strongly mediated by local influences. Typically three generalised responses are identified (Carter, 1988): erosional (involving net loss of sediment offshore); rollover (involving maintenance of barrier sediment volume during transgression) and overstepping (stranding of barrier sediment on the continental shelf). To these can be added partial or total barrier breakdown, as sediment is sequestered in tidal deltas, leading to insufficient sediment volume to sustain barriers and their consequent demise in a process termed 'runaway barrier island transgression' (Fitzgerald et al., 2006).

Overstepping or breakdown of a barrier during rising sea level is likely to be associated with rapid rises in sea level such as those associated with meltwater pulses (Green et al., 2014). Overstepping involves near-instantaneous translation of the wave-influenced shoreline from the former barrier to the former back-barrier shoreline, which may be several kilometres distant. Such a future situation has been envisaged for sediment-poor barriers on the US east coast, including the Outer Banks (Riggs et al., 2011). Although barrier overstepping has been modelled in several studies (e.g. Cowell and Thom, 1994; Storms et al., 2002) it has been documented in only a few locations and has been attributed to combinations of rapid sea level rise accompanied by particularly favourable 
circumstances. These include early cementation (beachrock and aeolianite formation) (e.g. Gardner et al., 2005, 2007; Green et al., 2013, 2014), or gravel and boulder barrierswith long relaxation times (e.g. Forbes et al., 1991; Hartstein and Dickinson, 2000). Rieu et al. (2005) identified an extensive system of tidal channels preserved on the North Sea seabed associated with a barrier several kilometres seaward of the present coast. Although all but the deepest inlet fill facies associated with the former barrier were eroded during a subsequent rise in sea level, it was argued ( $p 409$ ) that "this field observation corroborates recent modelling results suggesting that rapidly rising sea level may create the conditions necessary for overstepping of sandy barriers". Subsequent work in the Rhine delta (Hijma et al., 2010) also pointed to a phase of barrier overstepping, but again, the former barriers were eroded by subsequent wave ravinement. Overstepping of two unconsolidated sand barriers identified by seismic profiling in the northern Adriatic were attributed, respectively, to rapid sea level rise during Meltwater Pulse (MWP) 1A, and a rapid increase in backbarrier accommodation facilitated by a decrease in back-barrier gradient during a subsequent slower rate of sea level rise (Storms et al., 2008). To our knowledge, this is the only account to date of overstepping and in situ preservation of an unconsolidated sandy barrier.

This paper describes the seismic stratigraphy of Tijucas Bay, southern Brazil, and interprets its late Pleistocene and Holocene evolution in relation to the adjacent strandplain sequence (Hein et al., 2016) and Holocene sea level change. A key component of the interpretation involves an overstepped sandy barrier. The conditions for barrier overstepping and preservation are discussed in the context of sea levelchange and environmental setting.

\section{Regional setting}

Tijucas Bay is a deep embayment on the Santa Catarina coast of southern Brazil (Fig. 1). It is bounded by high granitic promontories $8.5 \mathrm{~km}$ apart. Ocean waves are bimodal (Araujo et al., 2003) with wind waves from the east $(T=8 \mathrm{~s} ; \mathrm{Hs}=1.25 \mathrm{~m})$ and swell from the south $(\mathrm{T}=12 \mathrm{~s} ; \mathrm{Hs}$ (summer) $=1.25 \mathrm{~m} ; \mathrm{Hs}$ (winter) $=2 \mathrm{~m}$ ). Southerly waves prevail in winter and autumn and waves from the NE dominate in summer and spring. Tidal range averages $0.8 \mathrm{~m}$ and surges of up to $1 \mathrm{~m}$ occur (Truccolo et al., 2006). The area is also influenced by tidal currents entering and exiting northern Florianópolis Bay and by fluvial discharge from the Tijucas River (drainage area $=2420 \mathrm{~km}^{2}$; mean discharge $40 \mathrm{~m}^{3} \mathrm{~s}^{-1}$ ) (Buynevich et al., 2005).

The contemporary coast within the Tijucas embayment comprises a series of sand ridges and cheniers forming a strandplain (Hein et al., 2016) through which the modern Tijucas River meanders. The strandplain developed during a fall in sea level from the Mid Holocene to present (Hein et al., 2016) (Fig. 2). Santa Catarina and Arvoredo Islands, together with prominent mainland rock outcrops, shelter Tijucas Bay from oceanic waves, the energy of which is further dissipated across the gentle (1:400) nearshore slope (Klein and Menezes, 2001). Subaerial sandy beachridges continue to be deposited during periods of high energy (Schettini and Klein, 1997), landward of a muddy beachface and shoreface, as a result of wave winnowing of fine sediment. The contemporary seabed is characterized by mud on the modern shoreface and muddy sand seaward of the two enclosing headlands (Fig. 1).

Sea level in southern Brazil (Fig. 2) is poorly constrained before the Mid Holocene. Available data indicate that it rose from a minimum of -120 mat the last glacial maximum(Corrêa, 1996), to amidHolocene highstand of approximately $+3 \mathrm{~m} 5000 \mathrm{cal}$ yr BP after which it fell to the present level 
(Angulo and Lessa, 1997). Muchwork has been undertaken on the highstand and subsequent sea levels, but there is a paucity of earlier sea level data. Using a combination of geomorphic and sedimentological approaches with chronological control derived from lag gravels, Corrêa (1996) identified several potential periods of slow and rapid sea level rise that can be correlatedwith subsequentwork on possible meltwater pulses and intervening stillstands (e.g. Liu and Milliman, 2004). Of particular relevance to this paper is the fact that Corrêa (1996) identified a period of sea level stability at -20 to $-25 \mathrm{~m}$ "around $8000 \mathrm{ka}$ yr BP" (ca. 8850 cal yr BP). On the Tijucas floodplain Hein et al. (2016) dated in situ plant roots and wood at $-15 \mathrm{~m} \mathrm{MSL}$ to $8.6 \mathrm{ka}$ cal yr BP indicating sea level to have been below $-11 \mathrm{~m} \mathrm{MSL}$ at that time. These terrestrial units were capped by marine sediments indicating their inundation at some point thereafter. These are the oldest Holocene dates obtained by Hein et al. (2016), all older dates being firmly in the Pleistocene.

Milne et al.'s (2006) modelled sea level for Santa Catarina places sea level at 9 ka cal BP at-10 m, rising to $-5 \mathrm{~m}$ by $8 \mathrm{ka}$ cal BP ( $5 \mathrm{~mm} / \mathrm{yr}$ ) and reaching $0 \mathrm{mby} 7.6 \mathrm{ka}$ cal BP $(12.5 \mathrm{~mm} / \mathrm{yr})$. In northern Brazil, Boski et al. (2015) established sea level at $8 \mathrm{ka}$ cal BP to be around $-7 \mathrm{~m}$ and reported a rapid rise $(6.1 \mathrm{~mm} / \mathrm{yr})$ between 8.3 and $7.0 \mathrm{ka}$ cal $\mathrm{BP}$, followed by a slowing in the rate of subsequent rise. The onshore Tijucas valley fill was investigated by Hein et al. (2016) using cores and GPR, although the GPR typically penetrated only the uppermost prograding beachridge units. Radiometric dating provided a chronological framework for the valley fill. Hein et al. (2016) identified several distinctive units (I to VI) in the valley fill (Fig. 3). These are summarised below as they enable comparison with the offshore seismic units that are the focus of this paper. The basal Unit I is a coarse-grained, oxidised, poorly sorted angular to sub-angular silty coarse sand/granule with some larger pebbles. Its upper surface is a sharp contact that occurs at depths between $-11 \mathrm{~m}$ and $-21 \mathrm{~m} \mathrm{MSL}$. It was interpreted as a pre-Holocene fluvial deposit. Overlying this is a 0.5 to $6.0 \mathrm{~m}$-thick silty sand (Unit II), grading upwards to silty clay and medium/medium-coarse sand. Peat, root fragments, and shells in some cores identify the upper surface as subaerially exposed and radiocarbon dates (ca. $40 \mathrm{ka}$ yr BP) point to a Pleistocene age.

The basal section of Unit III is a silty clay with occasional sand stringers. The uppermost part of the unit is oxidised and contains rootlets, indicating subaerial exposure. Unit Illa is capped by a thin (1-2 $\mathrm{m}$ thick) unit (IIIb) of medium to coarse-grained sand with some shells. Unit IIla was interpreted as backbarrier lagoon and peat topped by transgressive shoreline deposits (Unit IIIb): the remnants of a transgressive barrier), which are best developed in the landward sections of the floodplain. Radiocarbon dating places this unit in the mid Holocene (9-6 ka yr BP).

Unit IV is the highstand shoreline deposits, dated at Tijucas to between $5.7 \mathrm{ka}$ and $6.0 \mathrm{ka}$, and comprising tidal channel and barrier overwash sequences deposited into back-barrier muds. The elevation of the highstand shoreline could not be precisely defined, but the elevation of back-barrier muds indicate it to have been at least $2 \mathrm{~m}$ above MSL. Unit $\mathrm{V}$ rests on a gently seaward-dipping surface on Unit III. It comprises clay with occasionally shelly layers and sand units up to 2 mthick. The unit is interpreted as a bayfill sequence whose age decreases in a seaward direction, consistent with progradation. The material was derived from the Tijucas River and the sandy units are attributed to periodic floods. The overlying Unit VI comprises the prograding barrier sediments of the contemporary strandplain. These were initiated during the late Holocene sea level highstand and prograded seawards across a planar surface of the Holocene bayfill sediments of Unit V. Progradation continues to the present. 


\section{Methods}

Over 100 line kilometres of seismic data were collected from the continental shelf between depths of $\sim 3$ and $\sim 15 \mathrm{~m}$ (Fig. 1) using anEdgetech (0.5-12 kHz) SB512 CHIRP system(resolution ca. $0.1 \mathrm{~m}$ ) and a 100J C-Boom boomer single channel seismic profiler (resolution ca. $0.2 \mathrm{~m}$ ) and C-Phone eight element hydrophone array. Navigation was acquired using a differential GPS with real-time correction. Boomer data were collected using the SonarWiz package, with a $100 \mathrm{~ms}$ sweep window and a $250 \mathrm{~ms}$ trigger interval. High and low band pass filtering of $1000 \mathrm{~Hz}$ and $250 \mathrm{~Hz}$ were applied to all boomer data respectively. Two-way travel time was converted to depth assuming the speed of sound in the water column as $1500 \mathrm{~m} / \mathrm{s}$ and a speed of sound of $1650 \mathrm{~m} / \mathrm{s}$ for the underlying stratigraphy. All isopach calculations and interpolations were derived from the digitising of key bounding reflectors in SonarWiz and converted to thicknesses in metres using the $1650 \mathrm{~m} / \mathrm{s}$ sound velocity value.

GPR and core data from the Tijucas strandplain (Hein et al., 2016) provide immediately adjacent onshore data and enable correlation with the acoustic facies identified on the inner shelf (Table 1). The cores also provide a chronological framework within which we interpret the temporal evolution of the offshore system.

\section{Results}

Seven seismic units (Units 1-7), separated by distinctive bounding surfaces (S1-7) were identified in both Chirp and Boomer records, although the degree of definition and penetration differs between the two approaches (cf. Plets et al., 2015). The successive units and bounding surfaces are described below and illustrated in Figs. 4 and 5 .

Unit 1 is marked by a high amplitude surface reflector with occasional hyperbolic returns. It has a highly irregular, high-relief surface topography (S1) and no internal structure was revealed. It occurs as isolated pinnacles throughout the study area and represents the acoustic basement.

Unit 2 is acoustically transparent and reaches thicknesses of at least $20 \mathrm{~m}$, extending beneath the penetration limit of our data. It abuts Unit 1 in places and appears to be present throughout the study area. Its upper surface (S2) comprises a planar to slightly undulating, low amplitude reflector.

Unit 3 consists of a series of laterally continuous, aggrading, alternating high and low amplitude reflectors with an overall draped configuration. It is widely developed in the study area and rests on the planar upper surface of Unit 2. In some instances it onlaps areas interpreted as a series of valley walls and interfluves (Figs. 4 and 5). In certain areas, the reflectors are contorted, with small scale depressions within the succession that are repeated conformably throughout (Fig. 5). This unit (and where it is absent, Unit 2) is truncated erosionally by Surface 3, a moderate amplitude, gently seaward dipping, near planar reflector.

Downlapping Surface 3 is Unit 4, (Figs. 4-5), preserved as two prograding, upwardly convex, sediment bodies that span the entire bay along coastal strike (Fig. 6). Both are up to ca. $20 \mathrm{~m}$ thick and are ca. $500 \mathrm{~m}$ to $1 \mathrm{~km}$ wide. The internal structure is variable, comprising occasional parallel or high angle tangential to sigmoid oblique reflectors that prograde seawards and landwards (Figs. 4, 5). Unit 4 rests on an eroded surface cut into unit 3 , or where it is absent, unit 2 . The top of unit 4 is marked by an irregular, high amplitude reflector, 
Surface 4, the topography of which is characterized by small cut and fill features with complex infilling patterns (Figs. 4 and 5). These consist of two distinct packages. To seaward, a series of retrograding high amplitude reflectors (Unit 5a) successively onlap a steeply dipping seawardsloping surface of Unit 4, and to landwards is a $25 \mathrm{~m}$-thick series of draped, alternating high and low amplitude reflectors with an overall draped configuration (Unit $5 b$ ) that successively onlap Unit 4 on its landward side. On some sections this unit is partially or completely obscured by gas blanking.

Unit $5 a$ thins seaward and is $10-30 \mathrm{~m}$ thick. It onlaps Unit 4 on its seaward side. It contains alternating high and low amplitude reflectors in a contorted and irregular pattern. In places, acoustically opaque vertical structures disrupt the original bedding. In others, apparent shear planes displace bedding on either side, and in some instances, floating blocks of apparently cohesive, bedded sediment rest within a series of chaotic reflectors (Fig. 7).

The small depressions on the upper surface of Unit 4 are filled by moderate amplitude onlapping drapes of Unit 6 (Figs. 4 and 5). Where Unit 6 extends above the small irregularities in the underlying surface, it is discontinuous and thin (b1 $\mathrm{m}$ ) and shows occasional progradational morphology to seaward (Fig. 5). The upper portions of Unit 5a are erosionally truncated by Surface 5, a moderate amplitude, gently seaward dipping reflector onto which the seaward portion of Unit 6 downlaps seawards. The upper part of Unit 6 and Unit 5 is erosionally truncated by Surface 6 .

Surface 6 is overlain by Unit 7, a $<20$-m thick unit comprising a series of moderate to low amplitude, parallel reflectors. These drape the lower unit boundary. Locally, an internal division can be made into a lower (planer bedded unit (7a) and an upper progradational unit, Unit 7b. The reflectors of Unit 7b downlap the upper-most parallel reflectors of Unit 7a. Internal reflector configuration can vary within Unit $7 b$, with very low-angle, low amplitude, sigmoid-oblique reflectors most common (Figs. 4 and 5).

Unit 7c forms the uppermost part of unit 7 and is conformable with the underlying parts. Chirp records show that $7 \mathrm{c}$ comprises an acoustically opaque upper layer that is truncated by the contemporary seafloor in the outer portion of the embayment (Fig. 8). The lower layer is an internally transparent drape that is common in saucer shaped depressions and isolated pools. Its lateral continuity both along strike and down dip is limited (Fig. 8).

\section{Discussion}

\section{Interpretation of seismic facies}

Our interpretations of the seismic stratigraphy are integrated with a series of onshore cores and GPR profiles presented by Hein et al. (2016) from the adjoining coastal plain (Table 1; Fig. 9). These provide constraint on the interpretation of the stratigraphic architecture of the embayment and help place the stratigraphy into a chronostratigraphic framework.

On the basis of the hard upper surface and lack of penetration, Unit 1 is interpreted as isolated pinnacles of the surrounding granite bedrock. This occurs as localised outcrops on the contemporary seabed and as offshore islands. 
Unit 2 is a structureless, transparent unit that occurs throughout the study area, except where bedrock protrudes. It is interpreted as a massive sandy deposit and by comparison with the onshore record, is interpreted as representing basal fluvial deposits of Quaternary age.

Based on the draped internal structure, the small scale contorted beds and overall aggrading arrangement of the reflectors Unit 3 is interpreted as an incised valley fill sequence preserved on the inner shelf. Identical seismic facies are documented from the Patos Lagoon in southern Brazil by Weschenfelder et al. (2014) and are ascribed to the central basin fill of a wave-dominated estuary (e.g. Zaitlin et al., 1994). Onshore cores contain a unit of alternating clays and fine sand (Unit II)whichwe regard as the equivalent of Unit 3; both core and seismic reflect the transgressive infilling of the palaeo-Tijucas River valley with fine-grained sediment. The truncating Surface 1 is interpreted as a tidal ravinement surface, formed by migration of tidal channels within a lagoon-estuarine complex during transgression. Dating of unit II onshore (Hein et al., 2016) shows it to be of Quaternary age (> 40 ka yr BP).

The prograding, mixed reflector configurations of Unit 4, together with the unit's lateral continuity along strike, are interpreted as a seaward- and alongshore-prograding sandy barrier system. It averages $500 \mathrm{~m}$ wide, is $20 \mathrm{~m}$ thick and extends across the bay (Fig. 6). The inner bay feature is interpreted as a coastal barrier that enclosed lagoonal sediments (unit $5 b$ ) and was flanked to seaward by shoreface sediments (unit $5 b$ ) (see below). The barrier is anchored on a pinnacle of granitic bedrock. The scale, internal orientation of the reflectors (seaward prograding arrangements) and the shore-parallel orientation of the deposit bear a strong resemblance to GPR radar-facies of contemporary barrier systems (cf. Van Heteren et al., 1998; Jol et al., 1996). Similar features have been documented from seismic investigations by Weber et al. (2004) and Green et al. (2015) from shelf and embayment settings and are directly comparable in terms of seismic architecture and geometry. Those examples were similarly interpreted as barrier systems that capped incised valley sequences. Similar features were also revealed from GPR profiles from the Pinheiras coastal plain south of the study area. These too were interpreted as relict barrier deposits buried in the strandplain stratigraphy (Hein et al., 2014).

The barrier position above a tidal ravinement surface is indicative of a phase of landward migration (rollover) during transgression, followed by stabilisation and vertical growth. The onlapping of units $5 \mathrm{a}$ and $5 \mathrm{~b}$ on seaward and landward margins of the barrier, respectively, point to a phase of barrier aggradation. That the draped back-barrier unit (5b) attains a thickness of $25 \mathrm{~m}$, is an indication of a prolonged period of barrier stability that was likely enhanced by the underlying bedrock on which the barrier is anchored.

A second, more seaward feature also composed of unit 4, is an elongate, shore-parallel sediment body. It has several internal reflectors reminiscent of palaeoland surfaces (undulating highs and lows). On its flanks are offlapping sigmoidal units that interdigitate with unit 7 (see below). The internal surfaces and offlapping units suggest vertical accretion (aggradation) of this feature. The location of the feature, its southward thinning, and its interdigitation with unit 7 (marine sediments) on both margins, support its interpretation as a tombolo/spit that gradually aggraded and was ultimately overstepped. Bedrock was imaged at the distal end of the feature and the abundance of high relief rocky outcrops and islands on the modern coast, coupled with the proximity of a modern tombolo (at Bombinhas, Fig. 1), lend support to this interpretation. 
Unit 5a is a disrupted and contorted unit of alternating sands and mud that is interpreted as a shoreface sequence. It onlaps unit 4 (barrier) and where the barrier surface elevation is low, extends over it, indicating ongoing shoreface translation after the barrier was inundated. The areas of contorted bedding are interpreted as water escape structures, but the widespread and disrupted nature of the bedding, including apparent shearing and floating blocks (brecciation?) is seldom reported in the literature from nearshore settings. Differential compaction is commonly responsible for generation of water escape structures, but the extent of disruption and shearing bears similarity to seismically induced deformation structures reported in Tertiary shelf sediments of China (Li et al., 2008). Neotectonic activity is known from the study area (Jacques et al., 2014). Activity on N-S faults is attributed to compressive interaction between the Nazca and South American plates, while E-W faults are extensional structures reactivated by expansion of the Mid-Atlantic ridge. The study area lies within a seismically-active zone that extends from Rio Grande do Sul to Espırito Santo. Seismic activity along the continental slope suggests a close relationship with flexural stresses caused by the weight of sediments and earthquakes with magnitudes larger than $5 \mathrm{mb}$ occur every 20-25 yr (Assumpcão et al., 2011).

Unit 5b, onlapping the landward margin of the barrier unit 4, is interpreted as a back-barrier lagoon sequence. The high incidence of gas blanking is attributed to high organic content in these sediments, which lends support to its interpretation as back-barrier sediments. The overall character and stratigraphic location of the gas is in keeping with the examples outlined by Weschenfelder et al. (2016). Although coeval with Unit 5a, its bedding shows no disturbance or water escape structures, suggesting it was protected from the processes seaward of the barrier that caused the disturbances. It is correlated with the onshore Unit IIla of Hein et al. (2016), interpreted as Holocene Lagoonal sediments.

Surface 4 is interpreted as the wave ravinement surface. It separates the barrier (Unit 4) fromthe overlying and abutting shoreface (Unit 5a). Seaward of the barrier, Surface 4 is marked by a seaward-dipping, planar erosion surface consistent with the geometry of wave ravinement profiles (Zecchin and Catuneanu, 2013). Over the barrier profile, Surface 4 is replaced by a series of small channels and surface irregularities. The undulations and irregularities on the upper barrier surface indicate rapid drowning that precluded, or minimised wave reworking, before it was buried and preserved under subsequent sediments.

Unit 5a is interpreted as a series of landward stepping, aggrading sandy shoreface deposits. These translate over the seaward front of the barrier of Unit 4 before pinching out against the uppermost portion of the barrier. No correlative deposits are found in the onshore records. The landward onlapping of this sandy unit against the barrier sands, is consistent with shoreface morphological adjustment following stabilisation of the barrier.

Unit 6 is associated with the transition from a gently seaward dipping wave ravinement surface to a channelised topography. The draped, low amplitude nature of the reflectors of Unit 6 suggest suspension settling of material. We consider this as likely to have settled out after the wave base migrated over the barrier profile rapidly, causing in-place drowning and preservation of the underlying topography under a draped covering analogous to the healing phase wedge found on posttransgressive shelves (e.g. Posamentier and Allen, 1993), and the draped shallow marine muds deposited on un-eroded drumlins after rapid sea level rise (McCabe et al., 1998). The upper surface 
(S6) of this unit is planar and represents wave ravinement once sea level stabilised or the rate of sea level rise slowed. Unit 6 is interpreted as a transgressive sandsheet and is correlated with Unit IIIb found onshore (Hein et al., 2016). Preservation (non-ravinement) of the barrier surface topography and suspension settling of muds on the barrier surface, suggest a rapid rise in base level at this time. Preservation of rootlets in the underlying terrestrial surface in cores collected by Hein et al. (2016) also indicate rapid flooding and a lack of erosional activity, consistent with a rapid rise in sea level.

Overlying these units are the alternating, low amplitude series of parallel-layered and prograding deposits of Unit 7. We interpret these as muddy deposits based on their low amplitude seismic character, their draped nature, and the very low angles formed at the leading edge of the prograding units. Such factors imply a weakly cohesive nature, in keeping with fluid-rich mud. We consider the prograding units to represent renewed phases of mud deposition, probably via fluvial floods. Flood horizons are common in Unit $\mathrm{V}$ (Holocene Bay fill) in the adjacent onshore sequences cored by Hein et al. (2016) and with which we correlate unit 7. Unit 7c is considered to be compacted mud overlain by contemporary fluid mud that blankets the contemporary embayment floor (Buynevich et al., 2005; Schettini et al., 2010).

\subsection{Coastal evolution}

The seismic stratigraphy and onshore corematerial together provide insights into the evolution of the Tijucas Bay area since the late Pleistocene. Although the two datasets are immediately contiguous and separated by a short distance, we acknowledge that there is a lack of continuous connecting data between the onshore cores and the offshore data set. Though the correlations between the offshore-onshore units are not completely indisputable, the combination of the seismic architectural observations, and our interpretations thereof, pair well with the observed data from the cores of Hein et al. (2016). We consider that the depositional models we describe are consistent with the available data and in keeping with many other papers that derive environmental interpretations based on seismic data alone. Likewise, in the absence of direct dating of key offshore deposits, the linkages between onshore stratigraphy enable us to infer with a good level of confidence, the general chronological framework for the area. The absence of precise dates precludes the construction of a sea level curve in this paper.

The area is framed by high relief granitic bedrock which provides a strong geological control on past and present sedimentary environments and geomorphology. During Pleistocene lowsea levels, fluvial/alluvial sands (Unit 1 ) were deposited on an irregular granitic bedrock surface. During a Pleistocene transgression laminated lagoonal sediments (>40 ka yr BP), represented by onshore unit II (Hein et al., 2016) and seismic unit 3 were deposited. This was likely accompanied by landward barrier migration. A Late Pleistocene highstand barrier is preserved onshore (Hein et al., 2016).

Subsequent sea level fall to the LGM lowstand $(-120 \mathrm{~m})$ would have exposed the Pleistocene sediments subaerially and likely caused valley downcutting. This period is not represented in the seismic records. The lack of incised valleys is tentatively ascribed to the long distance to the shelf break (ca $140 \mathrm{~km}$ ).

During the Holocene transgression, wave ravinement of the Pleistocene alluvial and lagoonal deposits took place. A sandy barrier formed on an eroded surface of Pleistocene alluvial and lagoonal deposits. It migrated onshore, leaving small remnants that record its former position in 
bedrock depressions on the margins of Tijucas Bay. Barrier stabilisation (against a prominent bedrock outcrop) took place ca $-40 \mathrm{~m}$ MSL (base of barrier sequence). Formation of a tombolo/ spit between onshore and offshore rock outcrops also occurred at this time.

Both the barrier and tombolo/spit appear to have then remained stationary and undergone vertical accretion until sea level reached ca. -25 to $-20 \mathrm{~m}$ (top of the barrier unit). The sea level record suggests that time period during which this occurred is between 11.0 and $9.0 \mathrm{ka}$ cal BP, a period after MWP1B. This aggradation indicates high rates of longshore sediment supply to the barrier thatwere accompanied by apparently comparable rates of sedimentation in the back barrier and shoreface, preserved as draping laminated backbarrier sediments. Deposition of offlapping sandy units both seaward and landward of the tombolo/spit point to periods of instability or disequilibrium between sediment supply to the tombolo/spit and rates of nearshore aggradation. The continuity of modern depth contours suggest that North Bay had not been flooded and Tijucas was a shallow embayment north of a promontory that since become part of Santa Catarina island. Longshore sediment supply would therefore have been assured.

During this interval, the shoreface sediments (Unit 5a) appear to have been subject to extensive disturbance, resulting in contorted bedding, shearing, liquefaction and large-scalewater escape structures. The adjacent barrier and lagoonal deposits were not similarly affected. The extent of the disturbance is such that it is tentatively attributed to the effect of seismic activity on the mud-rich sediments, rather than simple compaction and dewatering.

Overstepping and drowning of the barrier is indicated by the preservation of the irregular barrier and tombolo/spit upper surfaces, and its draping by a thin transgressive shoreface unit (Unit 6 ). Unit 6 represents the initial adjustment during which topographical irregularities were preserved and smoothed by marine deposition, but the planar upper surface of unit 6 and the associated planation of adjacent exposed units after an initial pulse of sea level, point to the onset of wave ravinement processes. The depth at which the barrier was overstepped (ca. $25 \mathrm{~m}$ ) coincides with a period of rapid sea level rise between 8.8 and $8.0 \mathrm{ka}$ cal BP during which local sea levels seem to have risen from ca. $-20 \mathrm{~m}$ to $-7 \mathrm{~m}$ (16 mm/yr) according to modelled (Milne et al., 2005) andfield evidence (Corrêa, 1996) (Fig. 2). This spans the period of rapid global sea level rise associated with the onset of, (Kendall et al., 2008) or prelude to, (Hijma and Cohen, 2010) the 8.2 ka event, and a period when rapid sea level rise was recorded from one of the few detailed studies of evidence for lower than present Holocene sea level in Brazil (Boski et al., 2015).

Overstepping of the barrier caused the ocean shoreline to shift landwards to the landward margin of the former lagoon and initiated the transgressive sandsheet recorded in onshore cores by Hein et al. (2016) (their Unit IIIb). The dates recorded in the underlying flooded land surface (8.6 ka cal BP), lend support to the proposed timing of the overstepping and similarly agree with data from the Argentine coast (Prieto et al., 2016).

The magnitude of the implied rise in sea level cannot be determined directly from available field data, but for preservation of the barrier surface it must have been rapidly placed below wave base. Dalinghaus (2016) estimated the 'depth of closure' for nearshore environments of Santa Catarina Island using Hallermeier's (1981) equation. For wave-sheltered areas of ocean beaches, this was between 3 and $4 \mathrm{~m}$, increasing to $6 \mathrm{~m}$ for wave-exposed areas. For the sheltered location of Tijucas Bay, a value of 3-4mseems appropriate,whichmeans that sea level had to rise quickly by this 
amount, plus the elevation of the supratidal barrier (estimated at $2 \mathrm{~m}$ by comparison with modern features (Hesp et al., 2009).

Sea level continued to rise to the late Holocene highstand shoreline (+3 $\mathrm{m}$ at ca. $5.5 \mathrm{ka}$ cal yr BP) and suspension settling of fine material (Unit 7) took place across the flooded surface. Prograding units within Unit 7 and sandy units within the onshore cores point to periodic river flood-derived sediment inputs. With the fall from the mid-Holocene sea level maximum, a series of beachridges and cheniers developed that prograded over the former bayfill deposits (Hein et al., 2016). With stabilisation of sea levels and ongoing fluvial deposition, fluid mud accumulated on the contemporary sea bed.

\section{General discussion}

Overstepping of the former barrier by rapid sea level rise, caused a major change in the coastal sedimentary environment. It effectively decoupled sandy littoral sediments fromthe active shoreline, almost instantaneously shifting the shoreline from the barrier to the landward margin of the former back-barrier (over 7 km cross-shore distance). In so doing, it caused former muddy back-barrier sediments to be flooded and relocated into the active shoreface, creating the highly unusual conditions that persist to the present day, those of a muddy shoreface that is wave-reworked to maintain high levels of turbidity and a fluid mud unit on the sea bed (Schettini et al., 2010). At the same time, the availability of sand for highstand barrier construction would have been severely limited because of the stranding of the barrier sand on the shelf. The sequence of events outlined here has produced an unusual juxtaposition of barriers. An aggrading, stationary barrier is preserved on the shelf while a subsequent regressive barrier complex is deposited several kilometres landward. This contrasts markedly with other documented regressive coastline stratigraphies (e.g. McCubbin, 1981; Thom, 1984; Roy et al., 1994). The overstepping of the unconsolidated sandy barrier was facilitated by several factors.

1. Small tidal range. The probability of barrier-island overstepping during transgression is inversely proportional to tidal amplitude (Storms et al., 2008). The small tidal range limits processes for landward transfer of barrier sediment to overwash and thus inhibits landward transfer rates.

2. Wave-sheltered setting. The shelter afforded by the Santa Catarina and Arvoredo Islands and the adjacent prominent rocky headlands reduced wave energy, reducing the frequency of overwash and creating conditions favourable to overstepping both of the barrier and the tombolo/spit.

3. Rapid sea level rise. Corrêa's (1996) data places sea level in southern Brazil at between-20 and-25m at ca. $8.8 \mathrm{ka}$ cal BP. Deposition of bayfill sediments on top of terrestrial material from back-barrier cores (Hein et al., 2016), places the timing of overstepping to sometime before $8.6 \mathrm{cal}$ $\mathrm{yr}$ ka. Although imprecise, this is close to the $8.2 \mathrm{ka}$ yr global cooling event. Global sea level at that time is poorly constrained with some authors (e.g. Lambeck et al., 2014) claiming a constant rate of sea level rise between 11.4 and 8.2 ka yr BP, while others (e.g. Hijma and Cohen, 2010) provide convincing evidence of a global surge in sea level equivalent to ca. 3-4 m within $200 \mathrm{yr}$. GIA modelling (Kendall et al., 2008) points to maximum rates of sea-level rise during this event being on the east coast of South America. Considering local wave conditions, it is estimated above that migration of the surfzone over the submerged Tijucas barrier without significant erosion would require a rapid rise in sea level of ca. $6 \mathrm{~m}$. 
4. Barrier anchoring on rock outcrops. Prominent outcrops of bedrock occur under the main locations of the submerged barrier. These must have assisted in stabilising the barrier prior to the onset of aggradation. They, plus the large volume of accumulated sediment in the barrier, may have played a role in holding the barrier in position during overstepping.

5. Failure of sand supply. Continuity of depth contours suggests that Tijucas Bay was within the longshore drift system of the contiguous Santa Catarina Island until sea levels reached ca $-20 \mathrm{~m}$. When sea levels rose higher, the formation of the North Bay (Fig. 1), caused a break in the longshore sediment transfer system. This cut sand supply to the palaeo-Tijucas barrier, converting it to a discrete headland-embayment system with a finite barrier sand volume. The reduction in sand volume, and barrier attachment to granite headlands would then have facilitated overstepping.

The coastal evolution is similar to that envisaged in the near future for many of the world's barrierlagoon systems, including for example the Pamlico Sound and the Outer Banks of North Carolina (Riggs et al., 2011). Those authors contend that breakdown of the Outer Banks barrier system through limited sand supply at a time of rapid sea level rise will lead to massive open ocean shoreline relocation to the present marsh coast at the landward margin of Pamlico Sound, some 50 $\mathrm{km}$ landwards. The collapse of the large-scale fisheries, together with major losses in coastal infrastructure in the fringing back-barrier are theorised as just two of the possible negative outcomes. In our example, we show how a rapid rise in sea level led to overstepping and near geologically instantaneous inundation of a $7 \mathrm{~km}$ stretch of back-barrier environment.

The observed transformation of the entire coastal system from a barrier lagoon to a muddy strandplain may be indicative of near future changes in other barrier lagoon coasts.

\section{Conclusions}

Seismic stratigraphic evidence points to barrier overstepping and preservation following a period of rapid sea level rise on the southern Brazil coast, tentatively linked to the 8.2 ka Event. Overstepping caused a change in coastal geomorphology from a barrier-lagoon system to a muddy strandplain as sand was stranded on the shelf and removed from the contemporary littoral system. Factors that prompted overstepping include a small tidal range, low wave energy, breakdown of the longshore drift system, anchoring of a large volume barrier on bedrock, and rapid sea level rise. Subsequent sea level fall created a sand-poor strandplain. The resulting juxtaposition of transgressive and regressive sediment bodies is unlike that found elsewhere - the main transgressive unit is seaward of and contains a bigger volume of sand than the regressive unit. The changes observedmay be illustrative of near-future changes envisaged for barrier lagoon coasts.

\section{Acknowledgements}

We acknowledge the ConselhoNacional de Desenvolvivento Científico e Tecnológico (CNPq) for funding this project (grant: 313777/2013-6; 303550/2012-0; 400542/2013-7); the CNPQ - INCT Mar. COI “Oceanografia Integrada e Usos Múltiplos da Plataforma Continental e Oceano Adjacente. Centro de Oceanografia Integrada (COI)" for supporting the PVE project, and the Ciência Sem 
Fronteira Program for funding a visiting professorship for JAGC. We acknowledge helpful discussionwith JairWeschenfelder of UFRGS.

\section{References}

Angulo, R.J., Lessa, G.C., 1997. The Brazilian sea-level curves: a critical reviewwith emphasis on the curves from the Paranaguá and Cananéia regions. Mar. Geol. 140, 141-166.

Araujo, C.E.S., Franco, D., Melo, E., Pimenta, F., 2003. Wave regime characteristics of the southern Brazilian coast. Proc. 6th International Conference on Coastal and Port Engineering in Developing Countries, Sri Lanka. 97, pp. 1-15.

Assumpcão, M., Dourado, J.C., Ribotta, L.C., Mohriak, W.U., Dias, F.L., Barbosa, J.R., 2011.

The Sao Vicente earthquake of 2008 April and seismicity in the continental shelf off

SE Brazil: further evidence for flexural stresses. Geophys. J. Int. 187, 1076-1088.

Boski, T., Bezerra, F.H.R., Pereira, L.F., Souza, A.M., Maia, R.P., Lima-Filho, F.P., 2015. Sealevel rise since 8.2 ka recorded in the sediments of the PotengieJundiai estuary, NE brasil. Mar. Geol. 365, 1-13.

Buynevich, I., Asp, N., FitzGerald, D., Cleary, R., Klein, A.H.F., Siegle, E., Angulo, R., 2005. Mud in the surf: nature at work in a Brazilian bay. Eos 86, 301-302.

Carter, R.W.G., 1988. Coastal Environments: An Introduction to the Physical, Ecological and Cultural Systems of Coastlines. Academic Press, London.

Corrêa, I.C.S., 1996. Les variations du niveau de la mer durant les derniers 17.500 ans BP: l'exemple de la plate-forme continentale du Rio Grande do Sul-Bresil. Mar. Geol. 130, 163-178.

Cowell, P.J., Thom, B.G., 1994. Morphodynamics of coastal evolution. In: Carter, R.W.G., Woodroffe, C.D. (Eds.), Coastal Evolution: Late Quaternary Shoreline Morphodynamics. Cambridge University Press, pp. 33-86.

Dalinghaus, C., 2016. Análise da Estabilidade da Forma em Planta e Perfil nas Praias da Barra da Lagoa, Moçambique e Ingleses - Florianópolis - SC: Aplicações em Análises de Perigos Costeiros. MSc Thesis Universidade Federal de Santa Catarina. 
FitzGerald, D.M., Buynevich, I., Argow, B., 2006. Model of tidal inlet and barrier island dynamics in a regime of accelerated sea level rise. J. Coast. Res. Special Issue. 39 (II), 789-795.

Forbes, D.L., Taylor, R.B., Orford, J.D., Carter, R.W.G., Shaw, J., 1991. Gravel-barrier migration and overstepping. Mar. Geol. 97, 305-313.

Gardner, J.V., Dartnell, P., Mayer, L.A., Hughes Clarke, J.E., Calder, B.R., Duffy, G., 2005.

Shelf-edge deltas and drowned barrier-island complexes on the northwest Florida outer continental shelf. Geomorphology 64, 133-166.

Gardner, J.V., Calder, B.R., Hughes Clarke, J.E., Mayer, L.A., Elston, G., Rzhanov, Y., 2007. Drowned shelf-edge deltas, barrier islands and related features along the outer continental shelf north of the head of De Soto Canyon, NE Gulf of Mexico. Geomorphology 89, 370-390.

Green, A.N., Cooper, J.A.G., Leuci, R., Thackeray, Z., 2013. Formation and preservation of an overstepped segmented lagoon complex on a high-energy continental shelf. Sedimentology $60,1755-1768$.

Green, A.N., Cooper, J.A.G., Salzmann, L., 2014. Geomorphic and stratigraphic signals of postglacial meltwater pulses on continental shelves. Geology 24, 151-154.

Green, A.N., Cooper, J.A.G., Wiles, E.A., De Lecea, A.M., 2015. Seismic architecture, stratigraphy and evolution of a subtropical marine embayment: Maputo Bay, Mozambique. Mar. Geol. 369, 300-309.

Hallermeier, R.J., 1981. A profile zonation for seasonal sand beaches from wave climate. Coast. Eng. 4, 253-277.

Hartstein, N.D., Dickinson, W.W., 2000. Gravel barrier migration and overstepping in Cable Bay, Nelson, New Zealand. J. Coast. Res. SI 34, 256-266.

Hein, C.J., FitzGerald, D.M., deMenezes, J.T., Cleary,W.J., Klein, A.H.F., Albernaz, M.B., 2014. Sedimentological signatures of the mid-Holocene highstand in Brazil. Geol. Soc. Am. Bull. 126, 459-480. 
Hein, C.J., FitzGerald, D.M., de Souza, L.H.P., Georgiou, I.Y., Klein, A.H.F., Buynevich, I.V., Menezes, J.T., Scolaro, T., Cleary, W.J., 2016. Complex coastal change in response to autogenic basin infilling: an example from a sub-tropical Holocene strandplain. Sedimentology $63,1362-1395$.

Hesp, P.A., Giannini, P.C.F., Martinho, C.T., Silva, G.M., Neto, N.E.A., 2009. The Holocene barrier systems of the Santa Catarina coast, southern Brazil. In: Dillenberg, S.N., Hesp, P.A. (Eds.), Geology and Geomorphology of Holocene Coastal Barriers of Brazil. Springer-Verlag, Berlin, pp. 94-133.

Hijma, M.P., Cohen, K.M., 2010. Timing and magnitude of the sea-level jump preluding the 8200 yr event. Geology 38, 275-278.

Hijma, M.P., der Spek A.J.F., V., van Heteren, S., 2010. Development of a mid-Holocene estuarine basin, Rhine-Meusemoutharea, offshore theNetherlands.Mar.Geol. 271, 198-211. Jacques, P.D., Salvador, E.D., Machado, R., Grohmann, C.H., Nummer, A.R., 2014. Application of morphometry in neotectonic studies at the eastern edge of the Paraná Basin, Santa Catarina State, Brazil. Geomorphology 213, 13-23.

Jol, H.M., Smith, D.G., Meyers, R.A., 1996. Digital ground penetrating radar (GPR): a new geophysical tool for coastal barrier research (examples fromthe Atlantic, Gulf and Pacific coasts, USA). J. Coast. Res. 12, 960-968.

Kendall, R.A., Mitrovica, J.X., Milne, G.A., Törnqvist, T.E., Li, Y., 2008. The sea-level fingerprint of the 8.2 ka climate event. Geology 36, 423-426.

Klein, A.H.F., Menezes, J.T., 2001. Beachmorphodynamics and profile sequence for a headland bay coast. J. Coast. Res. 17 (4), 812-835.

Lambeck, K., Rouby, H., Purcell, A., Sun, Y., Sambridge, M., 2014. Sea level and global ice volumes from the Last Glacial Maximum to the Holocene. Proc. Natl. Acad. Sci. 111 (43), 15296-15303.

Li, S., Du, Y., Zhang, Z., Wu, J., 2008. Earthquake-related soft-sediment deformation structures in Palaeogene on the continental shelf of the East China Sea. Front. Earth Sci. 
China 2, 177-186.

Liu, J.P., Milliman, J.D., 2004. Reconsidering melt-water pulses 1A and 1B: global impacts of rapid sea-level rise. J. Ocean Univ. China 3, 183-190.

McCabe, A.M., Knight, J., McCarron, S., 1998. Evidence for Heinrich event 1 in the British isles. J. Quat. Sci. 13, 549-568.

McCubbin, D.G., 1981. Barrier-island and strandplain facies. In: Scholle, P.A., Spearing, D. (Eds.), Sandstone Depositional Environments. The American Association of Petroleum Geologists, Tulsa, Oklahoma, USA, pp. 247-280.

Milne, G.A., Long, A.J., Bassett, E., 2005.Modeling Holocene relative sea level observations form the Caribbean and South America. Quat. Sci. Rev. 24, 1183-1202.

Nordstrom, K.F., 2004. Beaches and Dunes of Developed Coasts. Cambridge University Press (187p).

Plets, R.K.M., Callard, S.L., Cooper, J.A.G., Long, A.J., Quinn, R.J., Belknap, D.F., Edwards, R.J., Jackson, D.W.T., Kelley, J.T., Long, D., Milne, G.A., Monteys, X., 2015. Late Quaternary evolution and sea-level history of a glaciated marine embayment, Bantry Bay, SW Ireland. Mar. Geol. 369, 251-272.

Posamentier, H.W., Allen, G.P., 1993. Variability of the sequence stratigraphic model: effects of local basin factors. Sediment. Geol. 86, 91-109.

Prieto, A.R., Mourelle, D., Peltier,W.R., Drummond, R., Vilanova, I., Ricci, L., 2016. Relative sea-level changes during the Holocene in the Río de la Plata, Argentina and Uruguay: a review. Quat. Int. (in press).

Rieu, R., van Heteren, S., van der Spek, A.J.F., De Boer, P.L., 2005. Development and preservation of a mid-Holocene tidal-channel network offshore the Western Netherlands.

J. Sediment. Res. 75, 409-419.

Riggs, S.R., Ames, D.V., Culver, S.J., Mallinson, D.J., 2011. The Battle for North Carolina's Coasts: Evolutionary History, Present Crisis, and Vision for the Future. University of North Carolina Press, Chapel Hill, NC (142p). 
Roy, P., Cowell, P.J., Ferland, M.A., Thom, B.G., 1994. Wave dominated coasts. In: Carter, R.W.G., Woodroffe, C.D. (Eds.), Coastal Evolution. Cambridge University Press, Cambridge, pp. 121-186.

Schettini, C.A.F., Klein, A.H.F., 1997. Aspectos da dinâmica sedimentar da Baía de Tijucas. Semana Nacional de Oceanografia, Itajaí, Resumos Expandidos. FACIMAR/UNIVALI. 10 pp. 493-495.

Schettini, C.A.F., de Almeida, D.C., Siegle, E., 2010. A snapshot of suspended sediment and fluid mud occurrence in a mixed-energy embayment, Tijucas Bay, Brazil. Geo-Mar. Lett. $30,47-62$.

Storms, J.E.A., Weltje, G.J., Dijke, J.J., Geel, C.R., Kroonenburg, S.B., 2002. Process-response modeling of wave-dominated coastal systems: simulating evolution and stratigraphy on geological timescales. J. Sediment. Res. 72, 226-239.

Storms, J.E.A., Weltje, G.J., Terra, G.J., Cattaneo, A., Trincardi, F., 2008. Coastal dynamics under conditions of rapid sea-level rise: Late Pleistocene to early Holocene evolution of barrier-lagoon systems on the northern Adriatic shelf (Italy). Quat. Sci. Rev. 27, $1107-1123$.

Stutz, M.L., Pilkey, O.H., 2011. Open-Ocean Barrier Islands: global influence of climatic, oceanographic, and depositional settings. J. Coast. Res. 27, 207-222.

Thom, B.G., 1984. Transgressive and regressive stratigraphies of coastal sand barriers in eastern Australia. Mar. Geol. 56, 137-158.

Truccolo, E.C., Franco, D., Schettini, C.A.F., 2006. The low frequency sea level oscillations in the Northern Coast of Santa Catarina, Brazil. J. Coast. Res. 39, 547-552.

Van Heteren, S., Fitzgerald, D.M., Mckinlay, P.A., Buynevich, I.V., 1998. Radar facies of paraglacial barrier systems: coastal New England, USA. Sedimentology 45, 181-200. Weber, N., Chaumillon, E., Tesson, M., Garlan, T., 2004. Architecture and morphology of the outer segment of a mixed tide and wave-dominated-incised valley, revealed by HR seismic reflection profiling: the palaeo-Charente River, France. Mar. Geol. 203, 
229-245.

Weschenfelder, J., Baitelli, R., Corrêa, I.C.S., Bortolin, E.C., dos Santos, C.B., 2014. Quaternary incised valleys in southern Brazil coastal zone. J. S. Am. Earth Sci. 55, 83-93.

Weschenfelder, J., Klein, A.H.F., Green, A.N., Aliotta, S., de Mahiques, M.M., Neto, A.A., Terra, L.C., Corrêa, I.C.S., Calliari, L.J., Montoya, I., Ginsberg, S.S., Griep, G.H., 2016.

The control of palaeo-topography in the preservation of shallow gas accumulation: examples from Brazil, Argentina and South Africa. Estuar. Coast. Shelf Sci. 172, 93-107.

Zaitlin, B.A., Dalrymple, R.W., Boyd, R., 1994. The stratigraphic organization of incised valley systems associated with relative sea-level change. In: Dalrymple, R.W., Boyd, R., Zaitlin, B.A. (Eds.), Incised Valley Systems: Origin and Sedimentary Sequences. Society for Sedimentary Geology, pp. 45-60 Spec. Publ., 51. SEPM.

Zecchin, M., Catuneanu, O., 2013. High-resolution sequence stratigraphy of clastic shelves I: units and bounding surface. Mar. Pet. Geol. 39, 1-25. 

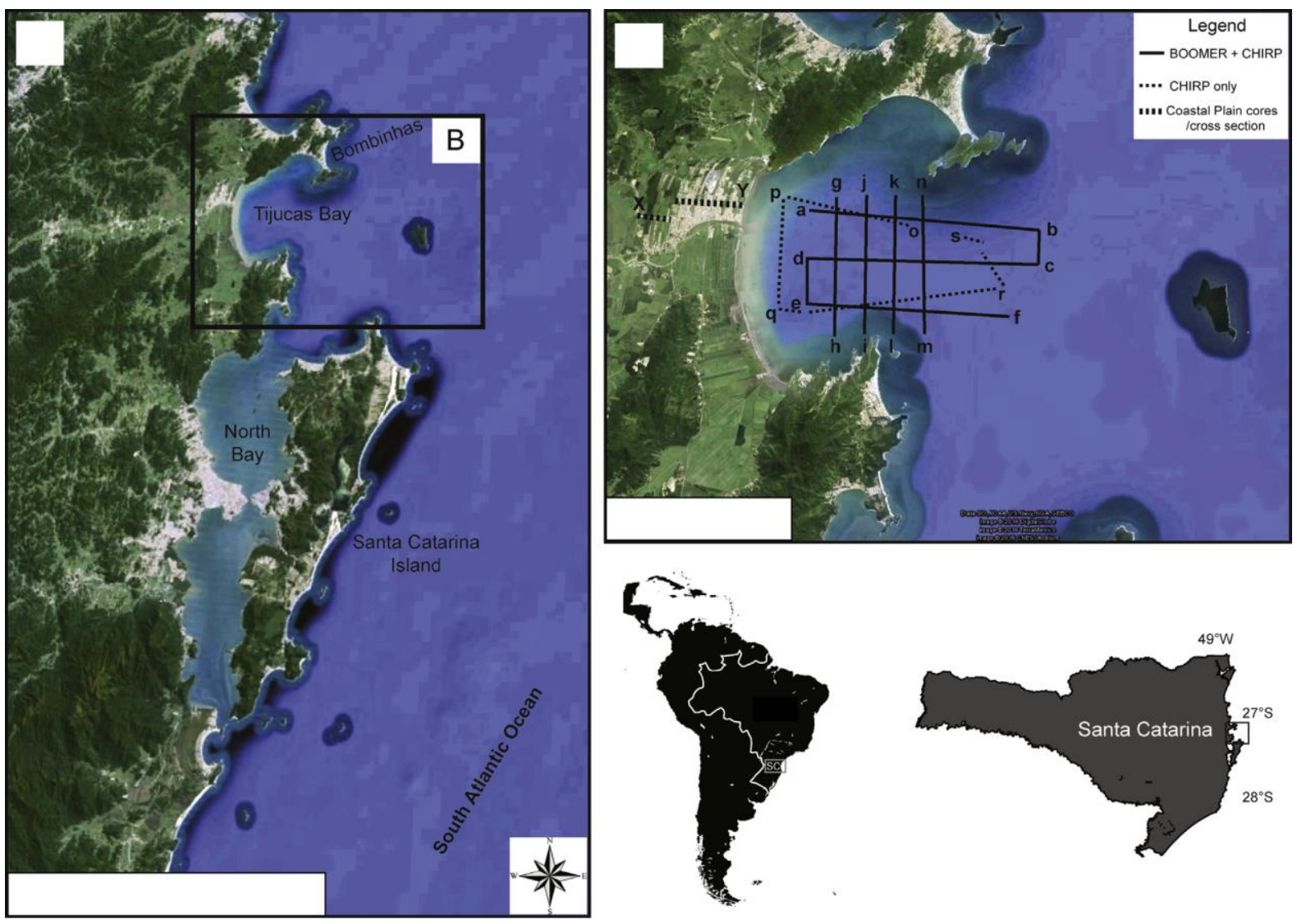

Fig. 1. Locality map of study area (A) showing Tijucas bay in relation to Santa Catarina Island and the adjacent North Bay.Note the tombolo at Bombinhas. (B) Position of cross-section (Fig.3) derived from onshore cores $(X-Y)$ and termination points of seismic reflection profiles (a-s). Satellite data from GoogleEarth ${ }^{\mathrm{Tm}}$. 


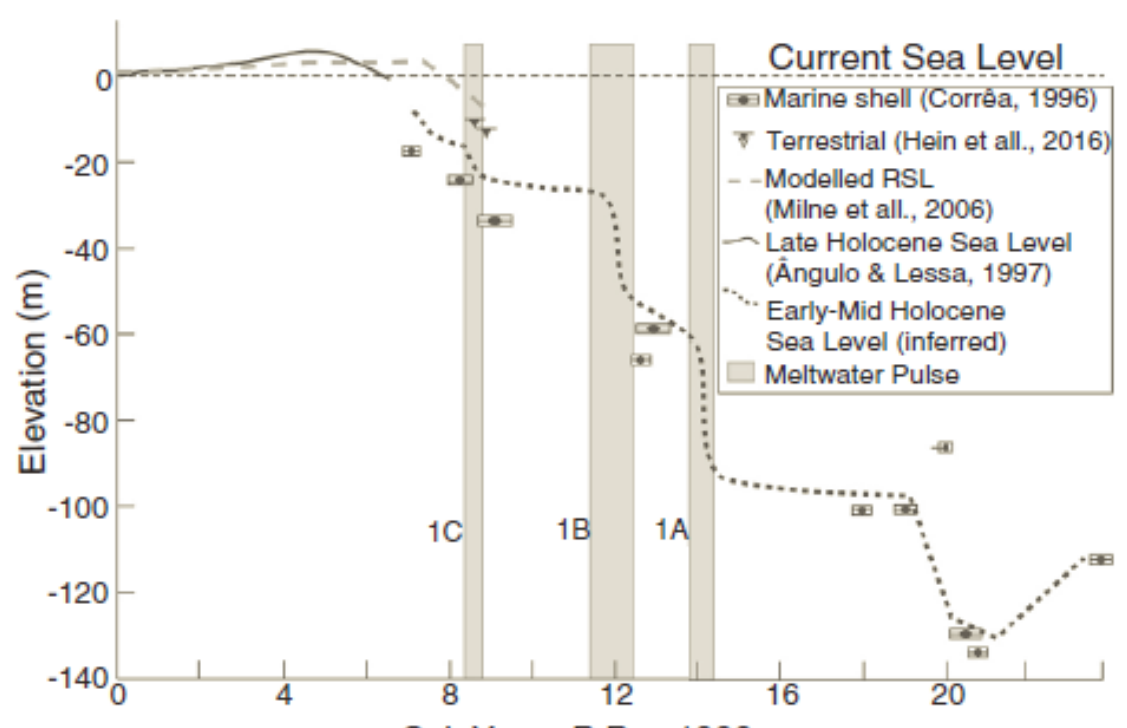

Cal. Years B.P. $x 1000$

Fig. 2. Holocene sea-level curve for southern Brazil drawn to take account of the timing of global meltwater pulses (Liu and Milliman, 2004; Hijma and Cohen, 2010). Elevations below MSL (after Corrêa, 1996, C14 dates converted to cal yr BP) are from gravels on planation surfaces, attributed to temporary stillstands of sea level. Late Holocene curve is from Angulo and Lessa (1997). Additional terrestrial limiting dates from Hein et al. (2016) are from rootlets in a terrestrial surface in the Tijucas floodplain sedimentary fill. Modelled sea level curve (dashed line) from Milne et al. (2005). 


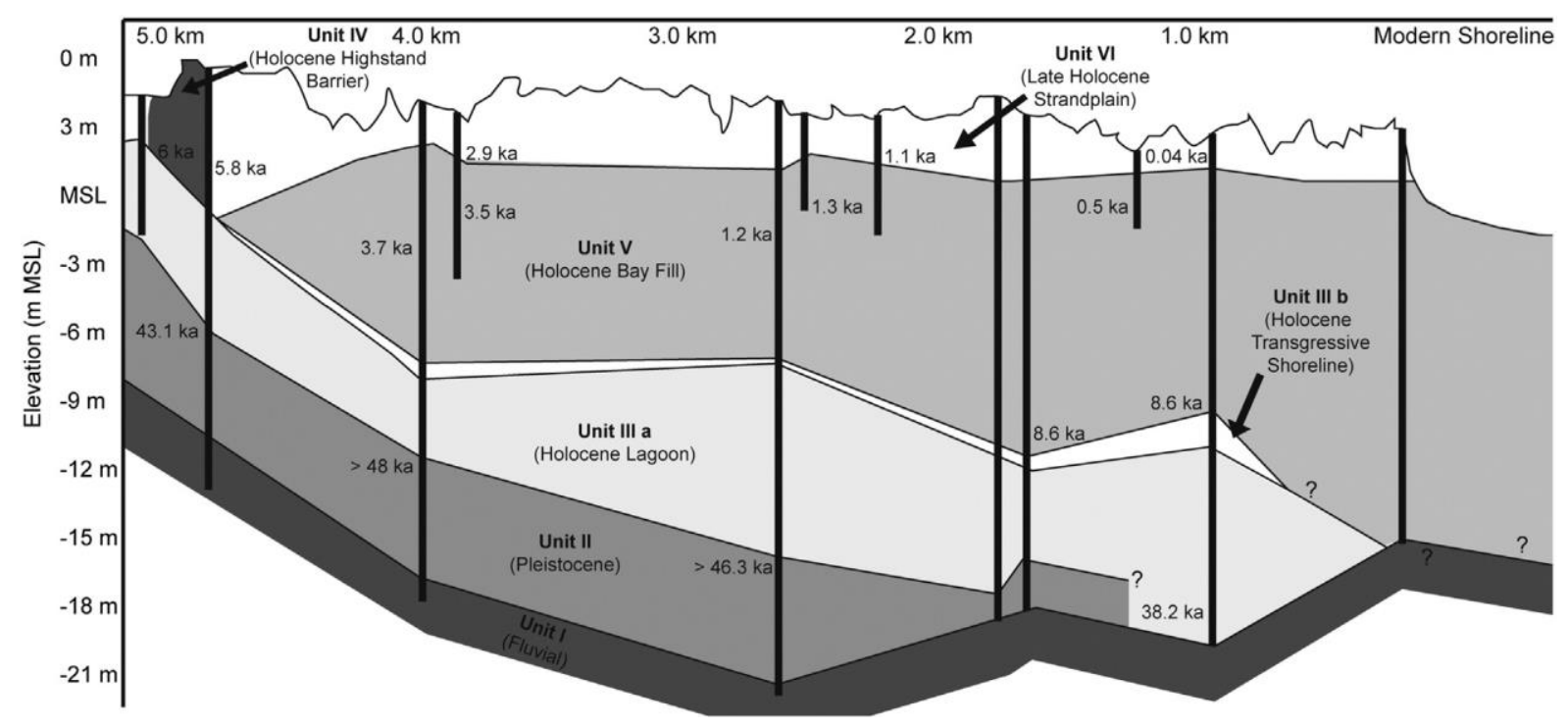

Fig. 3. Cross-section of onshore valley fill sequence showing main units and associated dates (after Hein et al., 2016). Section based on multiple cores, radiometric dating and lithological analysis. 
A

$B_{0(m)}$

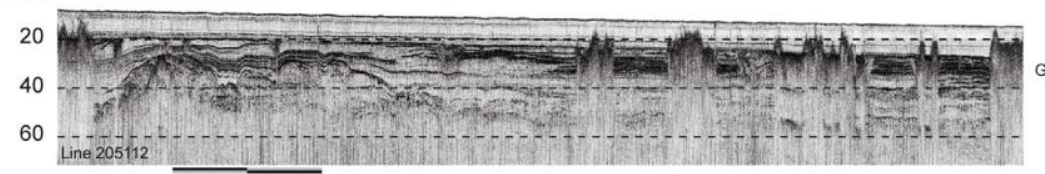

GAS

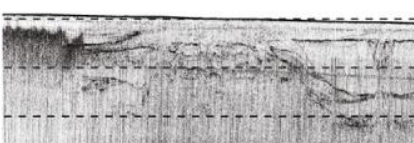

20

(m)

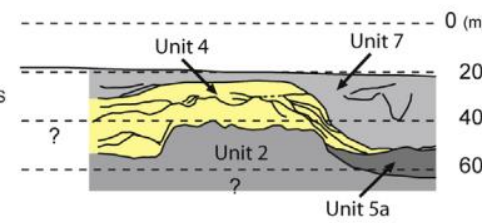

C
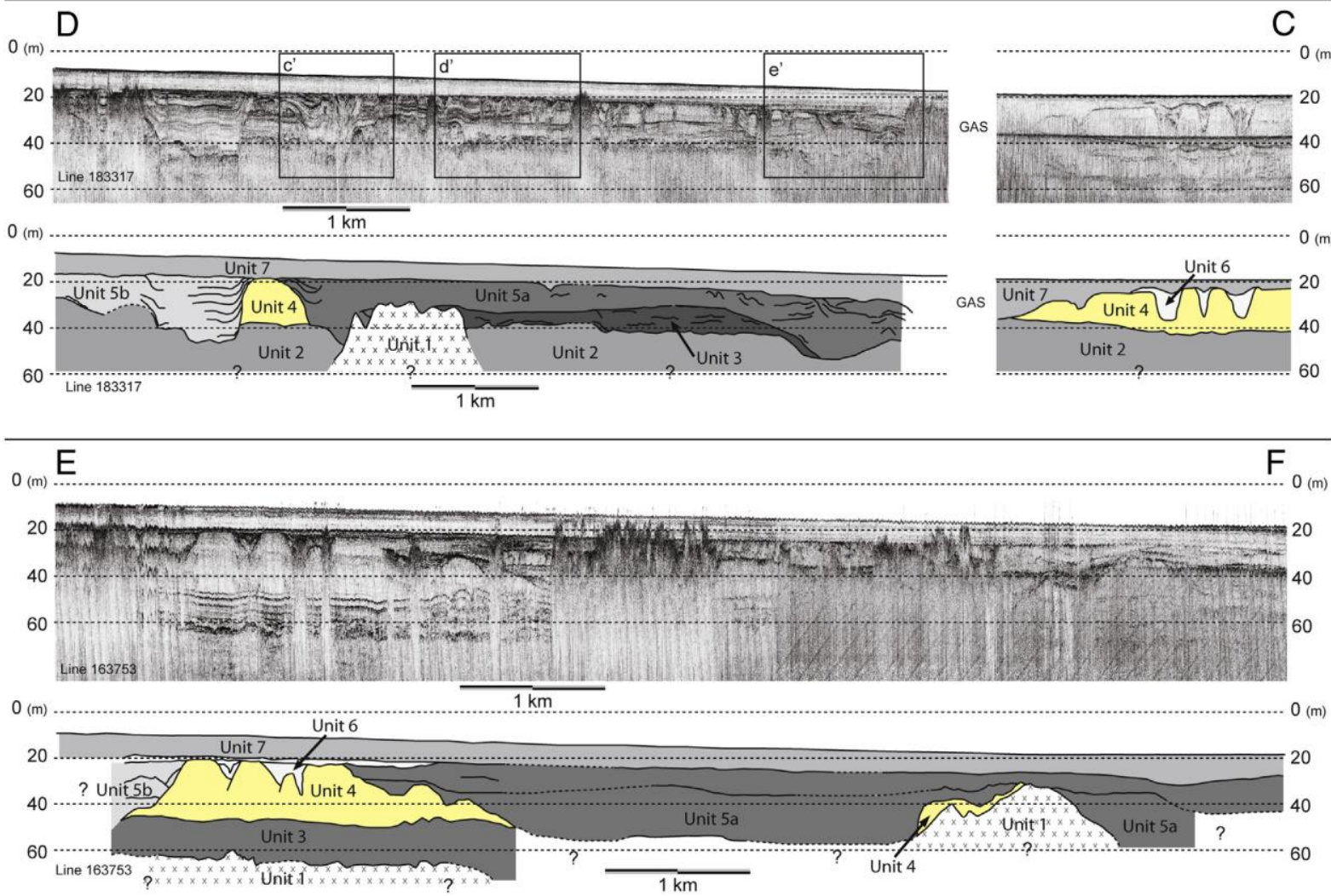

Fig. 4. Shore-normal Boomer seismic profiles and interpretations. For locations see Fig. 1. 


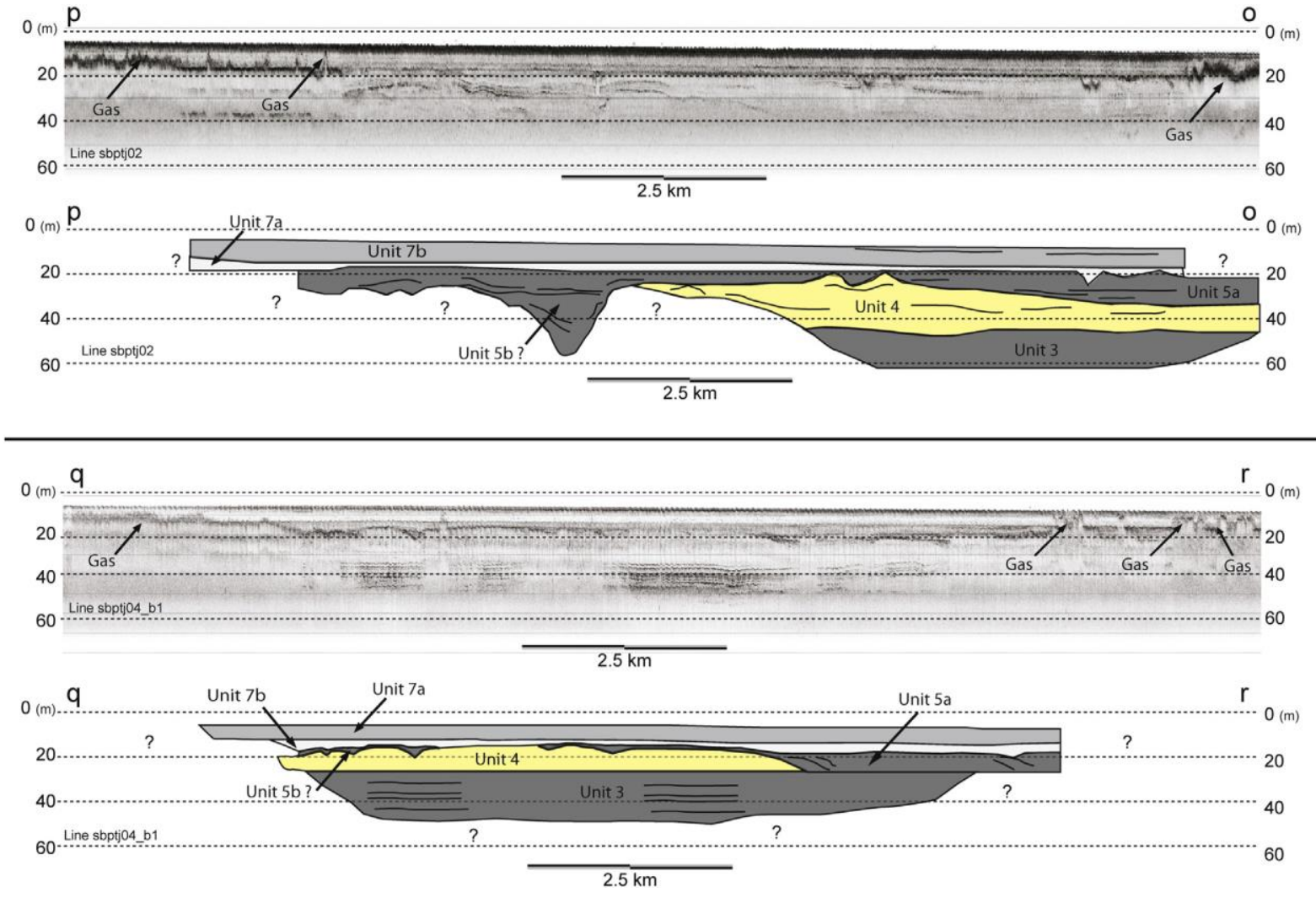

Fig. 5. High-resolution CHIRP seismic profiles and interpretative overlays detailing the upper stratigraphy of the Tijucas Bay. For locations see Fig. 1.

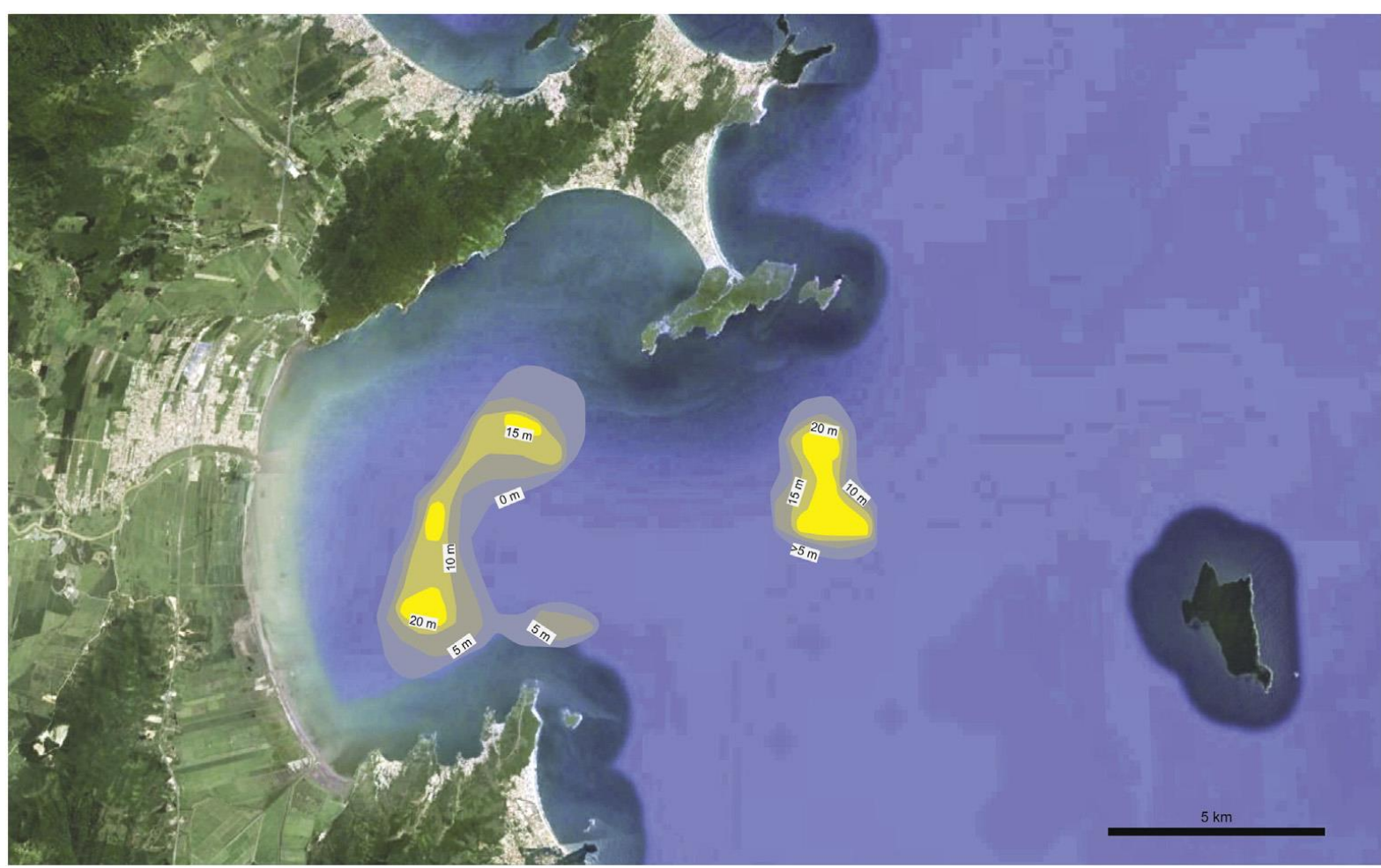


Fig. 6. Isopach map of unit 4 (barrier unit). The inner unit is the submerged barrier, while the outer unit is interpreted as a tombolo/spit, similar to that immediately adjacent in the modern coast. Satellite data from GoogleEarth ${ }^{\mathrm{TM}}$.
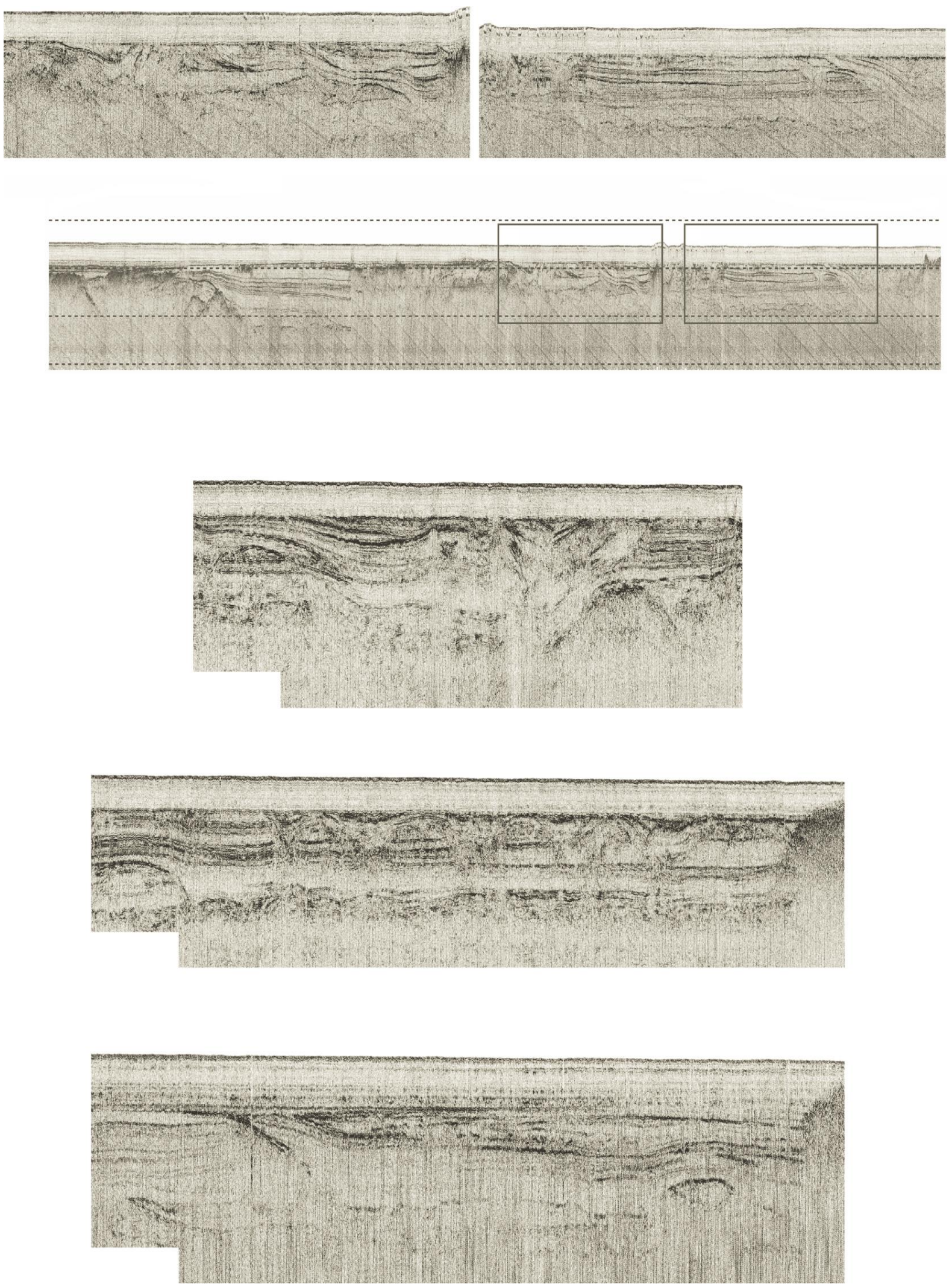
Fig. 7. Sections in Unit 5a (shoreface) showing contorted bedding, water escape structures, shear zones. Locations are provided in Fig. 1 ("j" to "l”, insets a' and b'). The location of insets $c^{\prime}, d^{\prime}$ and $e^{\prime}$ are provided on line " $c$ " to " $d$ " of Fig. 4.

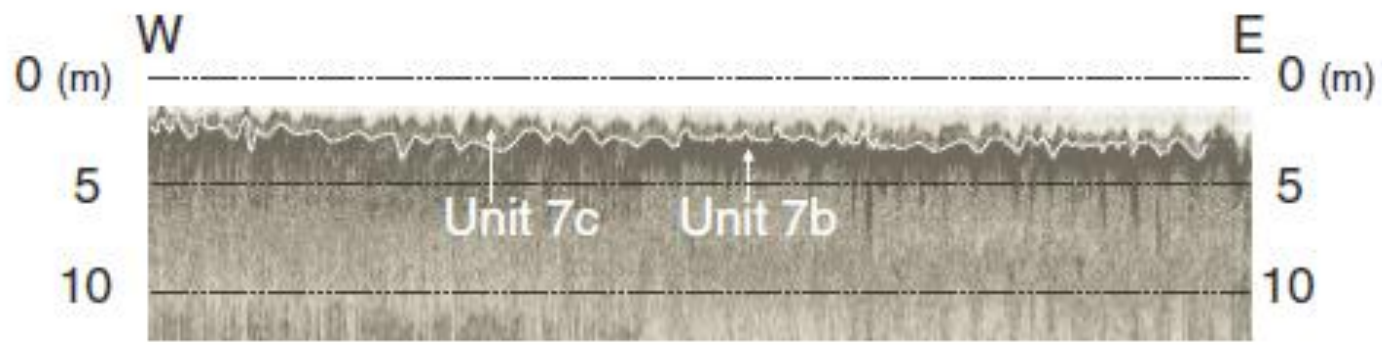

Fig. 8. High resolution CHIRP seismic profile detailing Unit 7. The uppermost part of the unit (7c) is relatively continuous down-dip and is marked by high acoustic opacity. Underlying it is an acoustically transparent unit (7b) that is common in saucer shaped depressions and isolated pools and has limited continuity both along strike and down dip. Data are from a small portion of the line "p" to "o".

\begin{tabular}{|c|c|c|c|c|}
\hline Boomer unit & Chirp unit & Onshore unit (Hein et al., 2016) & Description & Interpretation \\
\hline Surface 8 & Surface 8 & & & Contemporary sea bed \\
\hline \multirow[t]{3}{*}{7} & $7 \mathrm{c}$ & Modern seabed & $12 \mathrm{~m}$ thick muddy units & Modern mud \\
\hline & $7 \mathrm{~b}$ & Unit $\mathrm{V}$ & & Holocene Bay Fill \\
\hline & $7 a$ & Unit $V$ & & Holocene Bay Fill \\
\hline Surface 6 & Surface 6 & & & Erosional unconformity \\
\hline 6 & 6 & Unit IIIb & Discontinuous fill, draping lower surface & Transgressive sandsheet \\
\hline Surface 5 & Surface 5 & & & Undulating, overstepped topography \\
\hline $5 a$ & $5 a$ & Not present & Disturbed bedding, water escape structures and deformation & Shoreface \\
\hline $5 \mathrm{~b}$ & $5 b$ & Unit IIIa & Planar bedding, draped, $25 \mathrm{~m}$ thick, gas blanking & Holocene lagoon \\
\hline Surface 4 & Surface 4 & & & Undulating, onlapped topography \\
\hline Unit 4 & Unit 4 & Not present & Thick sand & Aggrading barrier \\
\hline Surface 3 & Surface 3 & & & Erosional unconformity \\
\hline Unit 3 & Unit 3 & Unit II & laminated clays ( $>40 \mathrm{ka} \mathrm{yr} \mathrm{BP}$ ) & Pleistocene lagoon \\
\hline Surface 2 & Surface 2 & & & Irregular undulating surface \\
\hline Unit 2 & Unit 2 & Unit I & Sands and gravel & Pleistocene fluvial sediments \\
\hline Surface 1 & Surface 1 & & & Undulating bedrock surface \\
\hline Unit 1 & Unit 1 & Granite bedrock & & Granitic bedrock \\
\hline
\end{tabular}

